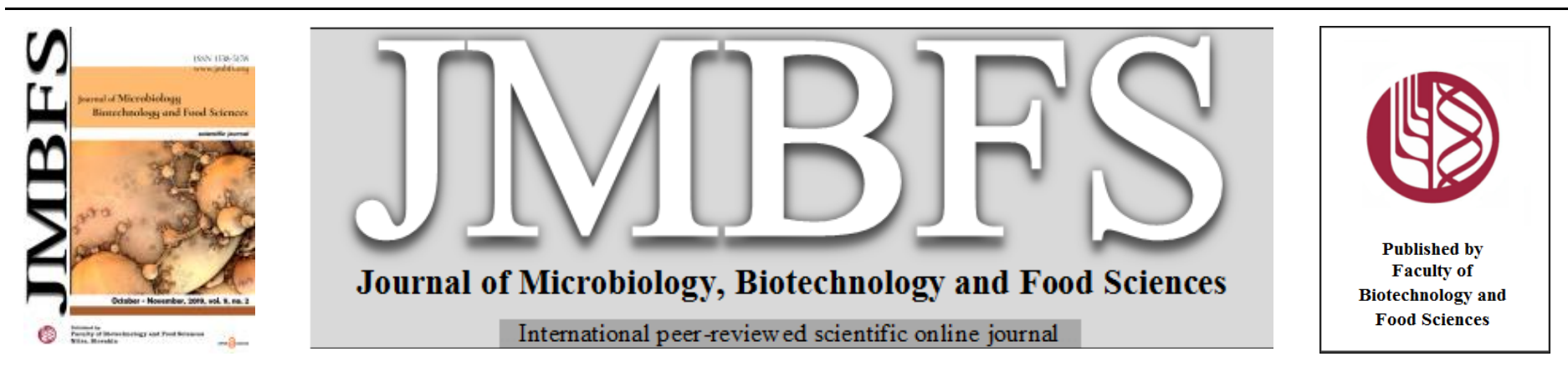

\title{
THE INFLUENCE OF GENOTYPE AND STORAGE CONDITION ON THE CONTENT OF SELECTED BIOACTIVE SUBSTANCES IN THE FRUIT OF PUMPKIN (CUCURBITA MOSCHATA DUCH.)
}

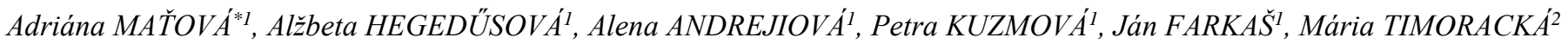 \\ Address(es): Mgr. Adriána Matová, \\ ${ }^{1}$ Slovak University of Agriculture in Nitra, Horticulture and Landscape Engineering Faculty, Department of Vegetable, Tr. A. Hlinku 2, 94976 Nitra, Slovakia. \\ ${ }^{2}$ Slovak University of Agriculture in Nitra, Faculty of Biotechnology and Food Sciences, Department of Chemistry, Tr. A. Hlinku 2, 94976 Nitra, Slovakia.
}

*Corresponding author: a.lidikova@gmail.com

doi: 10.15414/jmbfs.2019.9.2.288-292

ARTICLE INFO

Received 26. 10. 2018

Revised 3. 5. 2019

Accepted 3. 5. 2019

Published 1. 10. 2019

Regular article

OPEN $\partial_{\text {ACCESS }}$

\begin{abstract}
Butternut squash (Cucurbita moschata) is a significant crop in terms of the content of bioactive substances with antioxidant properties vitamin $\mathrm{C}$, vitamin $\mathrm{E}$, carotenoids, polyphenol compounds - as well as B-complex and potassium vitamins are appreciated by the consumer both raw and heat treated. It is suitable for storage, consumption in the fresh state or heat treatment thanks to its interesting sensory properties. The aim of the thesis was to evaluate the influence of genotype and storage conditions on the content of selected bioactive substances in the fruit of these six varieties: Liscia, Matilda F1, Orange, Serpentine, UG 205 F1 and Waltham F1. From bioactive substances we determined the content of total carotenoids and total polyphenols in the flesh of the fruits before and after storage. The total carotenoid content in the fruit before storage was in the range of $40.62 \mathrm{mg} .100 \mathrm{~g} \mathrm{~g}^{-1} \mathrm{DS}$ (dry substance) to $76.78 \mathrm{mg} .100$ $\mathrm{g}^{-1} \mathrm{DS}$, after storage the range transformed into $50.58 \mathrm{mg} .100 \mathrm{~g}^{-1}$ DS to up to $109.81 \mathrm{mg} .100 \mathrm{~g}^{-1}$ DS. The total polyphenol content before storage ranged from $109.95 \mathrm{mg}$ GAE. $100 \mathrm{~g}^{-1}$ DS to $198.96 \mathrm{mg}$ GAE.100 g ${ }^{-1} \mathrm{DS}$, after storage in the range of $152.51 \mathrm{mg}$ of GAE. $100 \mathrm{~g}^{-1}$ DS to $199.83 \mathrm{mg}$ of GAE. $100 \mathrm{~g}^{-1}$ DS. The results show that the highest content of total carotenoids in fresh fruits after harvest was determined in the pulp of the varieties UG $205 \mathrm{~F} 1\left(76.78 \mathrm{mg} .100 \mathrm{~g}^{-1} \mathrm{DS}\right)$, Orange (71.40 mg.100 g-1 DS), and high content of total polyphenols was determined in the Matilda F1 strains (198.96 mg GAE.100 g ${ }^{-1}$ DS) and Orange (166.09 $\left.\mathrm{mg} \mathrm{GAE} 100 \mathrm{~g}^{-1} \mathrm{DS}\right)$. After two months of the fruit's storage, the total carotenoid content significantly increased in Liscia by $91 \%$, Orange and Waltham F1 both by 54\%. The total polyphenol content considerably rose in Liscia and UG 205 F1 varieties by 39\%. The highest content of total polyphenols after storage was found in Serpentine fruit (199.83 mg GAE.100 $\left.\mathrm{g}^{-1} \mathrm{DS}\right)$. It follows that from the point of view of the content of total carotenoids it makes sense to store the fruits of the Orange and Waltham F1 varieties and, in terms of total polyphenols content, the fruits of the Serpentine variety. Taking into account the development of the contents of both groups of bioactive substances, storage of the Liscia variety is recommended. The effect of genotype on total carotenoid and polyphenol content in fruit was statistically significant. Storing these pumpkin varieties resulted in an increment of their total carotenoid and polyphenol content, but it did not have any statistical significance.
\end{abstract}

Keywords: Cucurbita moschata, carotenoids, polyphenols, storage

\section{INTRODUCTION}

Man has been pursued cultivation of important agricultural crops since ancient times. Traditional, but also less known fruits have represented in various fields of gastronomic, industrial and pharmaceutical spheres (Quintana et al., 2018). Cucurbita moschata belongs to the crops, which play an crucial role in the agricultural systems of the world.Currently, pumpkins are cultivated as a source of seeds, pumpkin oil (Pinke et al., 2018), edible flowers (Fernandes et al., 2017) and nutritionally valuable fruits. The aesthetic function of decorative varieties is also worth of mentioning. This annual plant belongs to the Cucurbitaceae family and is grown mainly for its fruits. However, cultivation of Cucurbita moschata in Slovakia is only at development stage being cultivated in small areas of the southern parts of Slovak territory (Andrejiová et al., 2016). Family of Cucurbitaceae is typical for its species diversity. Besides Cucurbita moschata, Cucurbita maxima DUCH, Cucurbita pepo L., Cucurbita ficifolia BOUCHÉ rank among important pumpkin species (Kuzmová, 2018). Still, there are significant differences between species in terms of nutrient content. There are various substances promoting health present in pulp of fruits, such as proteins, minerals, antioxidants - carotenoids and tocopherols (Kim et al., 2012). Cucurbita moschata is also known for its relatively high content of polyphenols, which form a big heterogeneous group of secondary metabolites (Sarah $\boldsymbol{e t}$ al., 2018). The content of these bioactive substances in fresh fruits is variable, they differ from one species to another, and can also be influenced by external factors - climate, nutrition, habitat, storage conditions, etc. The aim of this work was to determine the content of total carotenoids and total polyphenols which made up our selected representatives of bioactive substances in the fruit pulp before and after storage focusing on the evaluation of the genotype and storage effect on the content of these substances.

\section{MATERIAL AND METHODS}

In this work, we examined 6 different varieties of Cucurbita moschata Duch. namely Liscia, Matilda F1, Orange, Serpentine, UG 205 F1 and Waltham F1. The Liscia and Serpentine varieties are of czech origin from Semo a.s. company. Orange variety comes from Hungary, from ZKI-Vetömag Kft. company. The Matilda F1 variety pumpkins are from Netherlands, from Enza Zaden company. The Waltham F1 variety comes from the United States of America, from the Botanical interest Inc., the UG $205 \mathrm{~F} 1$ variety is of hungarian origin, from Orosco Kft. company. These pumpkin fruits are mainly used in the industrial processing sector. Samples of individual varieties of pumpkins were grown in the experimental fields of the SUA in Nitra. The growing cycle at the experiment location was initiated on 26th of April 2017. Sowing was realized on 3th of May 2017 and was followed by cultivating routine season. The cultivation area is located in a very warm agro-climatic region, characterized with a very dry subregion, the average annual temperature is $10{ }^{\circ} \mathrm{C}$ and the average annual rainfall is $584.5 \mathrm{~mm}$. The soil is characterized as a glue fluvisol, formed on alluvial sediments. The harvest was held on 27th of September 2017, and the fruits were more or less botanically mature, having a typical skin and pulp color, showing the best qualities in terms of growing conditions and circumstances. Fruits were primarily intended for storage and analysis. They were harvested 
manually and placed unwashed in the storage hall at the Department of Vegetable Production of Faculty of Horticulture and Landscape Engeneering on the Slovak University of Agriculture in Nitra. Storage took place from 27th of September 2017 to 1 th of December 2017, inclusive. The storage hall is covered, spacious, airy, without the possibility of storage conditions regulation (temperature, humidity). Storage was free, airy, on concrete floor according to varieties. Absenting regulation of storage conditions and uninsulated space caused storage conditions to be influenced by the development of outdoor weather. By lowering the outside air temperature, the temperature inside the hall also decreased, also the relative humidity of the air increased in the hall, as evidenced by a certain percentage of rotting fruit found at the beginning of December. The fruits were covered with a white nonwoven fabric to prevent the surface wetting of the fruits, its freezing and cold. The dry matter content was determined by gravimetric method. Homogenized samples were dried to a constant weight at $105{ }^{\circ} \mathrm{C}$ in a WTC Binder laboratory oven. The first serie of analyzes were realized as soon as possible after the harvest, the second serie of analyzes were carried out after two months of storage. The average samples were prepared by homogenizing 5 pumpkis for each variety. The total carotenoid content was determined spectrophotometrically at a wavelength of $450 \mathrm{~nm}$ on a Jenway UV-VIS device according to the methodology Hegedúsová et al. (2015). Total carotenoid content was recalculated according to the relationship reported by Biehler $\boldsymbol{e t}$ al. (2010). For the total polyphenols content evaluating, an average sample of fresh matter was lyophilized first. The total content of polyphenols was determined using the Folin-Ciocalteu reagent and gallic acid as the standard solution. Coloration intensity of the resulting solution was determined spectrophotometrically at $765 \mathrm{~nm}$ on a Shimadzu UV - 1800 spectrophotometer The results were expressed as mg of gallic acid (GAE) per kg of dry matter (DM), or more precisely - mg of gallic acid per $100 \mathrm{~g}$ of dry matter (DM). Al analyzes were performed in 2 parallels. The provisional conclusions were statistically verified using the statistical program Statgraphics Centurion XVI.I. (Statpoint Technologies, Inc.). Contrast testing was performed using the LSD test. For the standard deviation were chosen the total carotenoid content values in mg. $100 \mathrm{~g}^{-1} \mathrm{DM}$.

\section{RESULTS AND DISCUSSION}

The total carotenoid content was determined after harvest and after two month of storage in fruits of 6 different varieties of Cucurbita moschata. After the harvest, the average total carotenoid content in 100 grams of FM ranged from $3.20 \mathrm{mg} .100 \mathrm{~g}^{-1}$ (Serpentine variety) to $8.28 \mathrm{mg} .100 \mathrm{~g}^{-1}$ (Orange variety). By recalculation of the obtained value to the dry matter ratio, the total carotenoid content was achieved, ranging from $40.62 \mathrm{mg}$. $100 \mathrm{~g}^{-1}$ (Liscia variety) to 76.78 mg. $100 \mathrm{~g}^{-1}$ (variety UG $205 \mathrm{~F}$ ) (see Table 1).

Table 1 Total carotenoid content in Cucurbita moschata fruits after the harvest

\begin{tabular}{|c|c|c|c|c|c|}
\hline \multirow[b]{2}{*}{ Variety } & \multicolumn{5}{|c|}{ Total carotenoid content } \\
\hline & & $\begin{array}{l}\text { measurement } \\
1000 \mathrm{~g}^{-1} \mathrm{FM}\end{array}$ & $\begin{array}{l}\text { Average } \\
\text { mg.1000 } \mathrm{g}^{-1} \mathrm{FM}\end{array}$ & mg.100 $\mathrm{g}^{-1} \mathrm{FM}$ & mg.100 $\mathrm{g}^{-1} \mathrm{DM}$ \\
\hline \multirow{2}{*}{ Liscia } & I. & 52.65 & \multirow{2}{*}{$57.91 \pm 7.45$} & \multirow{2}{*}{5.79} & \multirow{2}{*}{40.62} \\
\hline & II. & 63.18 & & & \\
\hline \multirow{2}{*}{ Matilde } & I. & 60.75 & \multirow{2}{*}{$61.36 \pm 0.86$} & \multirow{2}{*}{6.14} & \multirow{2}{*}{66.05} \\
\hline & II. & 61.96 & & & \\
\hline \multirow{2}{*}{ Orange } & I. & 82.21 & \multirow{2}{*}{$82.82 \pm 0.86$} & \multirow{2}{*}{8.28} & \multirow{2}{*}{71.40} \\
\hline & II. & 83.43 & & & \\
\hline \multirow{2}{*}{ Serpentine } & I. & 33.61 & \multirow{2}{*}{$31.99 \pm 2.29$} & \multirow{2}{*}{3.20} & \multirow{2}{*}{47.46} \\
\hline & II. & 30.37 & & & \\
\hline \multirow{2}{*}{ UG 205 F1 } & I. & 62.37 & \multirow{2}{*}{$67.03 \pm 6.59$} & \multirow{2}{*}{6.70} & \multirow{2}{*}{76.78} \\
\hline & II. & 71.68 & & & \\
\hline \multirow{2}{*}{ Waltham } & I. & 59.94 & \multirow{2}{*}{$56.50 \pm 4.87$} & \multirow{2}{*}{5.65} & \multirow{2}{*}{54.32} \\
\hline & II. & 53.05 & & & \\
\hline
\end{tabular}

FM - fresh matter; DM - dry matter

A congenerous experiment with same varieties used has been done in SUA at the Department of Vegetable Production in 2013. In this experiment values ranged from 9.33 to $15.10 \mathrm{mg} .100 \mathrm{~g}^{-1}$ of FM, which was about $45-65 \%$ more than in 2017. By the dry weight conversion of the carotenoids content ranged from 67.05 to $150.44 \mathrm{mg} .100 \mathrm{~g}^{-1} \mathrm{DM}$, we also found values about $39-49 \%$ lower. The Orange variety dominated in the experiment again (Andrejiová et al., 2016). Carvalho et al. (2015) examined 20 different genotypes, while the total carotenoid content in the FM ranged from $12.46 \mathrm{mg} .100 \mathrm{~g}^{-1}$ to $69.9 \mathrm{mg} .100 \mathrm{~g} \mathrm{~g}^{-1}$. Priori et al. (2017) compared the variability of 10 genotypes. In terms of total carotenoid content, values ranged from $10.8 \mathrm{mg} .100 \mathrm{~g}^{-1} \mathrm{FM}$ to $36.7 \mathrm{mg} .100 \mathrm{~g}^{-1} \mathrm{FM}$. In both of the cases the fruits were grown under the brazilian climate conditions in both cases, which could have had a significant impact on the bioactivite properties of the pumpkin. Santos et al. (2017) analyzed Cucurbita moschata, the Menina brasileira variety, and found the average total carotenoid content in value of $24.80 \mathrm{mg} .100 \mathrm{~g}^{-1} \mathrm{FM}$, which is 3 times higher than our evaluated value for Orange variety (Table 1).

Table 2 Total carotenoid content in Cucurbita moschata fruits after the storage

\begin{tabular}{|c|c|c|c|c|c|}
\hline \multirow[b]{2}{*}{ Variety } & \multicolumn{5}{|c|}{ Total carotenoid content } \\
\hline & $\begin{array}{l}\mathrm{Pa} \\
\mathrm{mg}\end{array}$ & $-1 \quad$ measurement & $\begin{array}{l}\text { Average } \\
\text { mg.1000 g-1 }\end{array}$ & mg.100 $\mathrm{g}^{-1} \mathrm{FM}$ & mg.100 $\mathrm{g}^{-1} \mathrm{DM}$ \\
\hline \multirow{2}{*}{ Liscia } & I. & 78.16 & \multirow{2}{*}{$79.18 \pm 1.43$} & \multirow{2}{*}{7.82} & \multirow{2}{*}{77.76} \\
\hline & II. & 80.19 & & & \\
\hline \multirow{2}{*}{ Matilde F1 } & I. & 71.68 & \multirow{2}{*}{$67.23 \pm 6.30$} & \multirow{2}{*}{6.72} & \multirow{2}{*}{60.26} \\
\hline & II. & 62.77 & & & \\
\hline \multirow{2}{*}{ Orange } & I. & 101.65 & \multirow{2}{*}{$110.16 \pm 12.03$} & \multirow{2}{*}{11.02} & \multirow{2}{*}{109.81} \\
\hline & II. & 118.66 & & & \\
\hline \multirow{2}{*}{ Serpentine } & I. & 36.85 & \multirow{2}{*}{$36.65 \pm 0.29$} & \multirow{2}{*}{3.67} & \multirow{2}{*}{50.58} \\
\hline & II. & 36.45 & & & \\
\hline \multirow{2}{*}{ UG 205 F1 } & I. & 77.76 & \multirow{2}{*}{$80.39 \pm 3.72$} & \multirow{2}{*}{8.04} & \multirow{2}{*}{81.24} \\
\hline & II. & 83.02 & & & \\
\hline \multirow{2}{*}{ Waltham F1 } & I. & 93.15 & \multirow{2}{*}{$92.95 \pm 0.29$} & \multirow{2}{*}{9.30} & \multirow{2}{*}{83.71} \\
\hline & II. & 92.74 & & & \\
\hline
\end{tabular}

FM - fresh matter; DM - dry matter

On the other hand, other authors tested genotypes and determined values from $0.06 \mathrm{mg} .100 \mathrm{~g}^{-1} \mathrm{FM}$ to $3.00 \mathrm{mg} .100 \mathrm{~g}^{-1} \mathrm{FM}$ (Tamilselvi - Jansirani, 2017), although they were significantly lower compared to our experiment the scientists evaluated the situation very positively in terms of the next breeder's work. Muzzaffar et al. (2016) determined the average carotenoids value in fresh fluid $9,685 \mathrm{mg} .100 \mathrm{~g}^{-1}$, approximately similar $\left(9.29 \mathrm{mg} .100 \mathrm{~g}^{-1}\right)$ are reported by Pandey et al. (2003). In this work, we have determined a significantly lower value, only $5.96 \mathrm{mg} .100 \mathrm{~g}^{-1}$ of FM, which approximates the results reported by

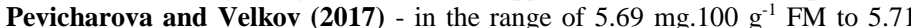
mg. $100 \mathrm{~g} \mathrm{~g}^{-1}$ FM. The carotenoids ratio in DM was in value from $45.53 \mathrm{mg} .100 \mathrm{~g}^{-1}$ to $55.35 \mathrm{mg} .100 \mathrm{~g}^{-1}$, which corresponds to our average value. We assume that the variability in carotenoids content depends not only on the genotype but is also corrected by other factors such as the specific cultivation location ((Shahidan $\boldsymbol{e t}$ al., 2014; Jaswir et al., 2014), climatic and environmental conditions during the 
cultivation (Iacuzzo - Dalla Costa, 2009; Conti et al., 2015), intensity of fertilization and nutrient amount (Biesiada et al., 2009). Last but not least, the fruits storage and the storage conditions have a share in the results. Rahman $\boldsymbol{e t}$ al. (2013) tested fruit storage under various conditions and observed a rapid decrease in $\beta$-carotene content due to its oxidation after 30 days of storage, as long as the air temperature was $27-31{ }^{\circ} \mathrm{C}$ and a relative humidity of $75-90 \%$. In our experiment, an increase in total carotenoid content (FM) was observed after two month of storage. In 100 grams of FM was detected content in the range of $3.67 \mathrm{mg} .100 \mathrm{~g}^{-1}$ (Serpentine variety) to $11.02 \mathrm{mg} .100 \mathrm{~g} \mathrm{~g}^{-1}$ (Orange variety), the situation was similar to the results of the first analysis. After the recalculation of total carotenoid content to DM he lowest value was recorded for the Serpentine variety $\left(50.58 \mathrm{mg} .100 \mathrm{~g}^{-1}\right)$, the highest in the Orange variety $\left(109.81 \mathrm{mg}^{-100 \mathrm{~g}^{-1}}\right)$ (see Table 2).

During the pumpkis storage, some physiological changes had been going on in fruits. It is reflected in fluctuation of the content of various compounds, including carotenoids. Zhang $\boldsymbol{e t}$ al. (2014) in his work states, that the increase in carotenoid content occurs at the same time by the starch degradation, which is probably related to the conversion of amyloplasts to chromoplasts, and may not be due only to significant biosynthesis. On the contrary, the analysis revealed a reduced activity of expression of carothenogenic genes as well as phytoene synthase. In most of the cases, after two months of storage, we have seen an increase in total carotenoid content. In the case of the Matilde variety, a slight decrease in the fresh fruit content was observed, which could have resulted from various exogenous and endogenous factors, storage conditions and biochemical processes. By monitoring the dynamics of changes of carotenoid composition after next 47 days of storage, a significant increase was observed, after a further two weeks the total carotenoid content decreased again. Jaswir et. al. (2014) reports, a similar fluctuation in values occurred over a period of six months, which was related to the variable dynamics of chemical reactions and the varying intensity of the development of the proportion of individual carotenes and xanthophylls present in fruits. Provesi et al. (2011) state the dynamics of carotenoid changes in Cucurbita moschata fruit - the Menina Brasileira variety after 180 days of storage. A significant decrease of lutein concentration was noted. The concentrations of $\zeta$-carotene, $\alpha$-carotene, all trans- $\beta$-carotene and their cis-isomers were not characterized by significant changes during storage.
Bonina-Noseworthy et al. (2016) also storaged Cucurbita moschata fruits of Waltham F1 and Puritan Butternut varieties for two months, while observing a values rising in the ranges from $4.2 \mathrm{mg} .100 \mathrm{~g}^{-1}$ to $14.5 \mathrm{mg} .100 \mathrm{~g}^{-1} \mathrm{DM}$ for values ranging from $8.4 \mathrm{mg} .100 \mathrm{~g}^{-1}$ to $23.9 \mathrm{mg} .100 \mathrm{~g}^{-1}$, which shows to be about $50 \%$ more than our results. Conti et al. (2015) investigated the dynamics of changes in individual carotenoids ( $\alpha$-carotene, $\beta$-carotene, lutein) during storage. While the $\alpha$-carotene level reached a peak after 120 days of storage, $\beta$-carotene content directly increased proportionally with an increasing number of days. The initial total carotenoid content was $16.94 \mathrm{mg} .100 \mathrm{~g} \mathrm{~g}^{-1} \mathrm{DM}$. The total carotenoid content also reached the highest value after 120 days of storage $\left(54.06 \mathrm{mg}^{-100 \mathrm{~g}^{-1}}\right.$ DM). In this work, similarly as in our the Waltham F1 variety has been analyzed. Our ratio of carotenoids in DM after two months of storage was $89.38 \mathrm{mg} .100 \mathrm{~g}$

1. It shows that our fruits have been in this term nutritionally more worthwhile. Zaccari et al. (2017) after four months of storage have determined carotene content in Butternut pumpkin fruits in value of $71.3 \mathrm{mg} .100 \mathrm{~g}^{-1} \mathrm{DM}$ (varieties Atlas F1 and Sakata). After further two months of storage, the total carotenoid content has increased 0.7 times when converting to DM. Based on the exact results, we can assume that the total carotenoid content is influences by the genotype and corrected by both positive and negative additional effects in a certain extent. One of the these effects is also storage, which in most of the cases affects positively the total carotenoid content, so far the adequate storage conditions are maintained. The most pronounced increase in total carotenoid content in FM was observed in the Waltham F1 variety (64\% difference) followed by the Liscia variety (37\% difference) and Orange (33\% difference). By recalculating the total carotenoids content to DM, the highest differences can be observed with Liscia (91\%), followed by Waltham F1 and Orange (54\%), in the Matilde F1 variety a 9\% decrease was observed in total carotenoids after two months of storage. On the basis of our results, we found a certain increase in total carotenoid content in pumpkin fruits during the storage, but with statistical testing, it was shown that the difference in the results before and after storage was statistically insignificant $(\mathrm{P}>0.05)$. By analyzing the average sample of the lyophilized pulp of Cucurbita moschata, we determined values after the harvest of total polyphenols ranging from $109.95 \mathrm{mg}$ GAE. $100 \mathrm{~g}^{-1} \mathrm{DM}(\mathrm{G} 205 \mathrm{~F} 1)$ to 198.96 mg GAE.100 g g $^{-1}$ DM (Matilda F1 variety) (see Table 3).

Table 3 Total polyphenol content determined in lyophilised pumpkin matter after the harvest in mg GAE.100 g $\mathrm{g}^{-1}$ dry matter

\begin{tabular}{ccccccc}
\hline no. & Liscia & Matilde F1 & Orange & Serpentine & UG 205 F1 & Waltham F1 \\
\hline I. & 141.61 & 197.82. & 157.48 & 139.22 & 108.53 & 132.09 \\
\hline II. & 133.45 & 198.73 & 169.72 & 142.24 & 109.10 & 125.75 \\
\hline III. & 131.19 & 199.18 & 176.07 & 147.78 & 107.96 & 126.20 \\
\hline IV. & 133.91 & 198.73 & 172.44 & 142.24 & 109.54 & 132.09 \\
\hline V. & 137.99 & 198.28 & 161.56 & 149.29 & 113.09 & 123.94 \\
\hline VI. & 137.99 & 201.00 & 159.29 & 149.29 & 116.51 & 127.56 \\
\hline $\mathbf{X}_{\text {average }}$ & $\mathbf{1 3 6 . 0 2} \pm 3.83$ & $\mathbf{1 9 8 . 9 6} \pm 1.10$ & $\mathbf{1 6 6 . 0 9} \pm 7.67$ & $\mathbf{1 4 5 . 0 1} \pm 4.32$ & $\mathbf{1 0 9 . 9 5} \pm 4.22$ & $\mathbf{1 2 7 . 9 4} \pm 3.42$ \\
\hline $\mathbf{X}_{\text {average }}-$ the average value & & & & &
\end{tabular}

Kalkan and Yücecan (2013) report an average value of polyphenols $173.09 \mathrm{mg}$ GAE.100 $\mathrm{g}^{-1}$. Zhao et al. (2015) analyzed four different varieties of pumpkins grown in China (Miben, Hongli, Lvli, Xihulu). By recalculating the obtained values to dry matter, average values of the total polyphenols showed in three cases ranging from $110.22 \mathrm{mg}$ of GAE. $100 \mathrm{~g} \mathrm{~g}^{-1}$ DM to $138.90 \mathrm{mg}$ of GAE. $100 \mathrm{~g}^{-1}$ $\mathrm{DM}$, thus approximating our results. The Lvli variety exceeded even our highest value, with its value ranging of $236.49 \mathrm{mg}$ GAE. $100 \mathrm{~g} \mathrm{~g}^{-1}$ DM. Mendelová $\boldsymbol{e t ~ a l}$. (2017) investigated similar varieties as in our experiment, but determined the total polyphenols content in fresh fruits significantly higher than $443.98 \mathrm{mg}$ GAE.100 g ${ }^{-1}$ DM to 565.44 mg GAE.100 g-1 DM. Bahramsoltani et al. (2017) reported the total polyphenols content in iranian pumpkin extracts of up to 2292 mg of GAE.100 g-1 DM, Dirim and Calıșkan (2012) by analyzing the powder from lyophilized pumpkin puree have presented a total polyphenol content of 21.847 mg.100 g-1 DM. Dinu et al. (2016) have compared romanian varieties of Cucurbita moschata, Cucurbita maxima DUCH and Cucurbita pepo L. to demonstrate the variability in the biochemical composotion. Two of the observed variants indicated after recalculation to DM, the total polypehonols content in the range of $375.26 \mathrm{mg}$ GAE. $100 \mathrm{~g} \mathrm{~g}^{-1} \mathrm{DM}$ and $1441.30 \mathrm{mg}$ GAE. $100 \mathrm{~g}^{-1} \mathrm{DM}$ Difference between these varieties showed more than $70 \%$. Existence of significant differences in nutritional and antioxidative value of selected genotypes has been also demonstrated by Javaherashti et al. (2012). In their attempts, the Ziaber variety clearly dominated. The average values of total polyphenols in the pulp of the Cucurbita moschata fruits has been as well reported by Ellong et al. (2015) and achieved $27.03 \mathrm{mg}$ GAE.100 $\mathrm{g}^{-1} \mathrm{FM}$ and $31.5 \mathrm{mg}$ GAE. $100 \mathrm{~g}^{-1}$ FM. Muangthai et al. (2014) examined the impact of the growing season character to biosynthesis of polyphenol compounds in selected vegetable species. For most of the selected vegetable, a higher content of polyphenols has been determined as long as the temperature during the vegetation period has been lower. On the other hand, the edible tomato reached its maximum of $135.76 \mathrm{mg}$ GAE. $100 \mathrm{~g}^{-1} \mathrm{FM}$ when the vegetation period was sunny and warm. The polyphenol content in Cucurbita moschata was positively influenced by excessive rainfall during vegetation. Gazmer $\boldsymbol{e t}$ al. (2017) add, that the total polyphenol content also can be affected by the size of the fruits and in most of the cases dominate in physiologically mature fruits. Tamer $\boldsymbol{e t}$ al. (2010) reported an average value of $476.63 \mathrm{mg}$ of GAE.100 $\mathrm{g}^{-1}$ of polyphenol compounds in the pumpkin pulp. Zdunić et al. (2016) indicates a much lower total polyphenol content in FM, only $90.59 \mathrm{mg} \mathrm{GAE} .100 \mathrm{~g}^{-1}$. Last but not least, storage can also affect the content of polyphenols in raw material, but the extent of storage is not unambiguous due a wide range of polyphenol compounds with specific reactions on storage conditions (D'Archivio et al., 2010). Other authors report, that the storage of selected fruits and vegetables at $4{ }^{\circ} \mathrm{C}$ for 15 days had a positive effect on the increase of phenolic acids, but the total content of polyphenols was declining (Galani et al., 2017). An increase in the total polyphenols ( by $13-35 \%$ in DM) has been observed after 7 days long storage of summer squash variety Pattypan squash, on the other hand, in one case a decline of $12 \%$ has been observed as well. (Balbierz - Kołota, 2015). Priss (2016) also reports an increase in total polyphenols in fruits of Cucurbita pepo L. during storage. Zaccari et al. (2015) stored the pumpkin fruits for 6 months maximum. While the content of total polyphenols in DM decreased by $2 \%$ after first two months (from $357.7 \mathrm{mg} \mathrm{GAE} .100 \mathrm{~g}^{-1}$ to $350.89 \mathrm{mg} \mathrm{GAE} .100 \mathrm{~g}^{-1}$ ), the next two months of storage, a total content polyphenols in DM 52\% increase $(531.9 \mathrm{mg}$ GAE. $100 \mathrm{~g}^{-1}$ ) has been observed. Biesiada et al. (2011) stored for 90 days fruits of six varieties of Cucurbita maxima DUCH and six varieties of Cucurbita pepo L.. In both cases, both increase and the decrease of total polyphenols in DM has been detected, depending on the variety. In the case of Cucurbita maxima DUCH, the values before the storage ranged from 94.9 mg of GAE. $100 \mathrm{~g} \mathrm{~g}^{-1}$ to $276.30 \mathrm{mg}$ of GAE. $100 \mathrm{~g} \mathrm{~g}^{-1}$ and after the storage from $131.87 \mathrm{mg}$ of GAE. $100 \mathrm{~g}^{-1}$ to $364.30 \mathrm{mg}$ GAE. $100 \mathrm{~g} \mathrm{~g}^{-1}$; in case of Cucurbita pepo L., the results of analyses ranged from $263.21 \mathrm{mg}$ of GAE. $100 \mathrm{~g}^{-1}$ to $423.67 \mathrm{mg}$ of GAE. $100 \mathrm{~g}^{-1}$ before the storage and from $254.47 \mathrm{mg}$ of GAE. $100 \mathrm{~g}^{-1}$ to $376.43 \mathrm{mg}$ GAE. $100 \mathrm{~g}^{-1}$ after the storage. Analyses after two months of storage determined the total polyphenol 
contents in the range of $152.51 \mathrm{mg}$ of GAE.100 $\mathrm{g}^{-1}$ (variety UG $205 \mathrm{~F} 1$ ) to

$199.83 \mathrm{mg}$ of GAE. $100 \mathrm{~g}^{-1}$ (Serpentine) lyophilised matter (Table 4)

\begin{tabular}{|c|c|c|c|c|c|c|}
\hline no. & Liscia & Matilde F1 & Orange & Serpentine & UG 205 F1 & Waltham F1 \\
\hline I. & 185.13 & 152.04 & 189.67 & 203.18 & 15.55 & 164.28 \\
\hline II. & 186.95 & 156.12 & 188.31 & 200.16 & 152.98 & 165.19 \\
\hline III. & 188.31 & 157.03 & 191.02 & 197.14 & 152.41 & 165.19 \\
\hline IV. & 191.02 & 152.49 & 189.67 & 197.14 & 150.13 & 159.75 \\
\hline V. & 188.31 & 160.65 & 190.57 & 199.15 & 151.84 & 161.11 \\
\hline $\mathbf{x}_{\text {average }}$ & $187.70 \pm 20.21$ & $154.60 \pm 40.92$ & $190.72 \pm 23.41$ & $199.83 \pm 25.22$ & $\mathbf{1 5 2 . 5 1} \pm 14.15$ & $162.69 \pm 24.62$ \\
\hline
\end{tabular}

Comparing the total polyphenols content determined before storage and after the two months of storage, our results state an increase of $14-39 \%$ in 5 cases. In one case (the Matilde variety), we registered a decrease of $22 \%$. Similar to the determination of total carotenoid content, we observed an increase by storage in total polyphenols content. By statistical testing $(\alpha=0.05)$, it was shown that the difference in pre- and post-storage results was not statistically significant $(\mathrm{P}>$ $0.05)$.

\section{CONCLUSION}

The aim of this work was to evaluate the effect of genotype and storage on the content of total carotenoids and total polyphenols in fresh fruit of cucurbita moschata. We studied the variability of the chemical composition of six varieties of Cucurbita moschata: Liscia, Matilde F1, Orange, Serpentine, UG 205 F1 and Waltham F1. We observed, that the effect of the genotype on the content of total carotenoids and total polyphenols was statistically significant both, before storage and after storage. By storing we recorded an increment in total polyphenols and total carotenoids in fresh fruits of pumpkin, but these differences were not statistically significant. The highest content of total carotenoids in fresh fruits after harvest was recorded in the pulp of the varieties UG $205 \mathrm{~F} 1(76.78 \mathrm{mg} .100$ $\left.\mathrm{g}^{-1} \mathrm{DM}\right)$, Orange (71.40 mg.100 $\left.\mathrm{g}^{-1} \mathrm{DM}\right)$ and high content of total polyphenols was recorded in the Matilde F1 (198.96 mg of GAE.100 $\left.\mathrm{g}^{-1} \mathrm{DM}\right)$ and Orange (166.09 mg of GAE.100 $\mathrm{g}^{-1} \mathrm{DM}$ ) varieties. In terms of bioactive substances supply, cultivation and consumption of the varieties mentioned above are of great relevance to the consumer. After harvesting botanically mature fruits, 64-day storage of products in the storage hall was followed. We observed a significan increment in total carotenoids in Liscia varieties (by 91\%), Orange and Waltham F1 (both 54\%) and an increment in total polyphenols in Liscia and UG 205 F1 varieties (by $39 \%$ ) after the storage process. A $38 \%$ increase in the total polyphenols was also recorded in the Serpentine variety and we have also determined the highest total polyphenol content after storage of $199.83 \mathrm{mg}$ of GAE.100 $\mathrm{g}^{-1} \mathrm{DM}$ in this variety. The results showed, that from the point of the dynamics of changes in the total carotenoid content, storing fruits of the Orange and Waltham F1 varieties is of great significance. Serpentine fruits can be considered as an interesting source of polyphenols in winter, although the content of total carotenoids does not stay high. Considering the development of the content of both groups of bioactive substances, the Liscia variety could be advised as an adequte pumpkin variety to store.

Acknowledgments: This work was supported by grant VEGA 1/0087/17 and by AgroBioTech Research Centre built in accordance with the

project Building „AgroBioTech" Research Centre ITMS 26220220180

\section{REFERENCES}

ANDREJIOVÁ, A., HEGEDÜSOVÁ, A., ŠLOSÁR, M., BARÁTOVÁ, S. 2016. Dynamics of Selected Bioactive Substances Changes in Cucurbita Moschata Duch. Ex Poir. After Storage and Different Methods of Technological Processing. Acta Universitatis Agriculturae et Silviculturae Mendelianae Brunensis, 64(2), 387-393. ISSN 1211-8516. https://doi.org/10.11118/actaun201664020387

BAHRAMSOLTANI, R., FARZAEI, M. H., ABDOLGHAFFARI, A. H., RAHIMI, R., SAMADI, N., HEIDARI, M., SOLTANI, S. 2017. Evaluation of phytochemicals, antioxidant and burn wound healing activities of Cucurbita moschata Duchesne fruit peel. Iranian journal of basic medical sciences, 20(7), 798. doi: 10.22038/IJBMS.2017.9015

BALBIERZ, A., KOŁOTA, E. 2015. Pre-and postharvest nutritional value and storage ability of scallop squash cultivars. Journal of Horticultural Research, 23(2), 105-110. ISSN 2300-5009. https://doi.org/10.2478/johr-2015-0021

BIEHLER, E., MAYER, F., HOFFMANN, L., KRAUSE, E., BOHN, T. 2010 Comparison of 3 Spectrophotometric Methods for Carotenoid Determination in Frequently Consumed Fruits and Vegetables. Journal of food science, 75(1), 5561. doi:10.1111/j.1750-3841.2009.01417.x
BIESIADA, A., NAWIRSKA, A., KUCHARSKA, A., SOKÓŁ-ŁĘTOWSKA, A. 2009. The effect of nitrogen fertilization methods on yield and chemical composition of pumpkin (Cucurbita maxima) fruits before and after storage. Vegetable Crops Research Bulletin, 70, 203-211. ISSN 1898-7761. doi https://doi.org/10.2478/v10032-009-0020-0

BIESIADA, A., NAWIRSKA, A., KUCHARSKA, A., SOKÓŁ-ŁĘTOWSKA, A. 2011. Chemical composition of pumpkin fruit depending on cultivar and storage. Ecological Chemistry and Engineering. A, 18(1), 9-18. ISSN 1898-6188. BONINA-NOSEWORTHY, J., LOY, J. B., CURRAN-CELENTANO, J., SIDEMAN, R. KOPSELL, D. A. 2016. Carotenoid concentration and composition in winter squash: variability associated with different cultigens, harvest maturities, and storage times. Horticultural Science, 51(5), 472-480. ISSN 1805-9333. doi: https://doi.org/10.21273/HORTSCI.51.5.472

CARVAlHO, L. D., DE CARVALHO, J. L. V., BORGES, R., KASER, I. M., LIMA, V. G., SOUSA, D. D. 2015. Variability of total carotenoids in C. Moschata genotypes. In Embrapa Semiárido-Artigo em periódico indexado (ALICE), 44(1), 247-252. ISSN 2283-9216. https://doi.org/10.3303/CET1544042 CONTI, S., VILLARI, G., AMICO, E., CARUSO, G. 2015. Effects of production system and transplanting time on yield, quality and antioxidant content of organic winter squash (Cucurbita moschata Duch.). Scientia Horticulturae, $183, \quad 136-143 . \quad$ ISSN $0304-4238$ https://doi.org/10.1016/j.scienta.2014.12.003

D'ARCHIVIO, M., FILESI, C., VARÌ, R., SCAZZOCCHIO, B., MASELLA, R. 2010. Bioavailability of the polyphenols: status and controversies. International journal of molecular sciences, 11(4), 1321-1342. ISSN 1422-0067. https://doi.org/10.3390/ijms11041321

DINU, M., SOARE, R., HOZA, G., BECHERESCU, A. D. 2016. Biochemica composition of some local pumpkin population. Agriculture and Agricultural $\begin{array}{llll}\text { Science } & \text { Procedia, 10, 185-191. } & \text { ISSN } & 210-7843 .\end{array}$ https://doi.org/10.1016/j.aaspro.2016.09.051

DIRIM, S. N., ÇALISKAN, G. 2012. Determination of the effect of freeze drying process on the production of pumpkin (Cucurbita Moschata) puree powder and the powder properties. The Journal of Food, 37(4), 203-210. ISSN 1309-6273.

ELLONG, E. N., BILLARD, C., ADENET, S., ROCHEFORT, K. 2015 Polyphenols, carotenoids, vitamin $\mathrm{C}$ content in tropical fruits and vegetables and impact of processing methods. Food and Nutrition Sciences, 6(3), 299-313. ISSN 2157-9458. doi: $10.4236 /$ fns. 2015.63030

FERNANDES, L., CASAL, S., PEREIRA, J. A., SARAIVA, J. A., RAMALHOSA, E. 2017. Edible flowers: A review of the nutritional, antioxidant, antimicrobial properties and effects on human health. Journal of Food Composition and Analysis, 60, 38-50. https://doi.org/10.1016/j.jfca.2017.03.017 GALANI, J. H., PATEL, J. S., PATEL, N. J., TALATI, J. G. 2017. Storage of Fruits and Vegetables in Refrigerator Increases their Phenolic Acids but Decreases the Total Phenolics, Anthocyanins and Vitamin C with Subsequent Loss of their Antioxidant Capacity. Antioxidants, 6(3), 59. ISSN:2076-3921. https://doi.org/10.3390/antiox6030059

GAZMER, R., LASKAR, N., MANDAL, S. 2017. Physico-Chemical Characters of Pumpkin (Cucurbita moschata Duch.) Ex Poir Genotype against the Melon Fly (Bactrocera cucurbitae) Reveals Resistance Traits in the Terai Region of West Bengal, India. International journal of current microbiology and applied sciences, 6(10), 2023-2031. https://doi.org/10.20546/ijcmas.2017.610.239

ISSN 2319-7706. HEGEDÜSOVÁ, A, MEZEYOVÁ, I, ANDREJIOVÁ, A. 2015. Metódy stanovenia vybraných biologicky aktívnych látok (Determination methods of selected biologically active substances). Nitra: Slovak University of Agriculture, 72, ISBN 978-80-552-1420-7.

IACUZZO, F., DALLA COSTA, L. 2009. Yield performance, quality characteristics and fruit storability of winter squash cultivars in sub-humid areas. Scientia horticulturae, 120(3), 330-335. ISSN 0304-4238. https://doi.org/10.1016/i.scienta.2008.11.026

JASWIR, I., SHAHIDAN, N., OTHMAN, R., HASHIM, Y. Z. H. Y. OCTAVIANTI, F., BIN SALLEH, M. N. 2014. Effects of season and storage period on accumulation of individual carotenoids in pumpkin flesh (Cucurbita 
moschata). Journal of oleo science, 63(8), 761-767. ISSN 1347-3352. https://doi.org/10.5650/jos.ess 13186

JAVAHERASHTI, M., GHASEMNEZHAD, M., LAHIJI, H. S., SHIRI, M. A. 2012. Comparison of nutritional value and antioxidant compounds of some winter pumpkin (Cucurbita $\mathrm{sp}$ ) species fruits in Iran. Advances in environmental biology, 6(10), 2611-2616. ISSN 1995-0756.

KALKAN, I., YUCECAN, S. 2013. Stability of dietary phenolics and antioxidant properties of vegetables depends on cooking methodology. Müsbed, 3(5), 8-16. ISSN 2146-3654.

KIM, M. Y., KIM, E. J., KIM, Y. N., CHOI, C., LEE, B. H. 2012. Comparison of the chemical compositions and nutritive values of various pumpkin (Cucurbitaceae) species and parts. Nutrition research and practice, 6(1), 21-27. ISSN 2005-6168. http://dx.doi.org/10.4162/nrp.2012.6.1.21

KUZMOVÁ, P., HEGEDÜSOVÁ, A., ANDREJIOVÁ, A. 2018. Evaluation of the effect of genotype, storage and thermal processing on the content of selected bioactive substances in fruits of winter squash (Cucurbita moschata Duch.). Zbornik prispevkov zo študentskej vedeckej konferencie FZKI 2018, 43, ISBN 978-80-552-1960-8.

MENDELOVA, A., MENDEL, L., FIKSELOVÁ, M., MAREČEK, J., VOLLMANNOVÁ, A. 2017. Winter squash (Cucurbita moschata Duch.) fruit as a source of biologically active components after its thermal treatment. Potravinárstvo: Slovak Journal of Food Sciences, 11(1), 489-495. ISSN 1337-0960. doi: https://doi.org/10.5219/788

MUANGTHAI, P., WANWE, R., CHOLPITAKWONG, N., YOUPAISARN, P. 2014. Evaluation on Oxidative Stress Total Phenolic Compound Content and Antioxidation Inhibition Power in Variety Colored Vegetables. Asian Journal of Natural \& Applied Sciences, 3(4), 57-67. ISSN 2186-8476. doi: $10.17113 / \mathrm{ftb} .54 .04 .16 .4497$

MUZZAFFAR, S., BABA, W. N., NAZIR, N., MASOODI, F. A., BHAT, M. M. BAZAZ, R. 2016. Effect of storage on physicochemical, microbial and antioxidant properties of pumpkin (Cucurbita moschata) candy. Cogent Food \& Agriculture, 2(1), 1-13. ISSN 2331-1932. https://doi.org/10.1080/23311932.2016.1163650

PANDEY, S., SINGH, J., UPADHYAY, A. K., RAM, D., RAI, M. 2003. Ascorbate and carotenoid content in an Indian collection of pumpkin (Cucurbita moschata Duch. Ex Poir.). Cucurbit Genetics Cooperative, 26: 51-53. ISSN 1064-5594.

PEVICHAROVA, G., VELKOV, N. 2017. Sensory, chemical and morphological characterization of Cucurbita maxima and Cucurbita moschata genotypes from different geographical origins. Genetika, 49(1), 193-202. ISSN 1820-6069. doi:10.2298/gensr1701193p

PINKE, G., KARÁCSONY, P., CZÚCZ, B., BOTTA-DUKÁT, Z. 2018. When herbicides don't really matter: Weed species composition of oil pumpkin (Cucurbita pepo L.) fields in Hungary. Crop Protection, 110, 236-244. https://doi.org/10.1016/j.cropro.2017.06.018

PRIORI, D., VALDUGA, E., VILLELA, J. C. B., MISTURA, C. C., VIZZOTTO, M., VALGAS, R. A., BARBIERI, R. L. 2017. Characterization of bioactive compounds, antioxidant activity and minerals in landraces of pumpkin (Cucurbita moschata) cultivated in Southern Brazil. Food Science and Technology, 37(1), 33-40. ISSN 1678-457X. doi: $10.1590 / 1678-457 x .05016$

PRISS, O. 2016. Effect of heat treatment with antioxidants on the content of bioactive compouds during storage of zucchini. Technology audit and production reserves, 1(1), 72-76. ISSN 2226-3780. doi: https://doi.org/10.15587/23128372.2016 .60339

PROVESI, J. G., DIAS, C. O., AMANTE, E. R. 2011. Changes in carotenoids during processing and storage of pumpkin puree. Food Chemistry, 128(1), 195202. ISSN 0308-8146. https://doi.org/10.1016/j.foodchem.2011.03.027

QUINTANA, S. E., MARSIGLIA, R. M., MACHACON, D., TORREGROZA, E., GARCÍA-ZAPATEIRO, L. A. 2018. Chemical Composition and Physicochemical Properties of Squash (Cucurbita moschata) Cultivated in Bolivar Department (Colombia). Contemporary Engineering Sciences, 11(21), 1003 - 1012. https://doi.org/10.12988/ces.2018.8384

RAHMAN, M. A., MIARUDDIN, M., KHAN, M. H. H., MASUD, M. A. T., BEGUM, M. M. 2013. Effect of storage periods on postharvest quality of pumpkin. Bangladesh Journal of Agricultural Research, 38(2), 247-255. ISSN 2408-8293.

http://dx.doi.org/10.3329/bjar.v38i2.15888

SANTOS, JR. L. C. O., SIMÃO, V., DE ALMEIDA, J. D. S. O., DE SENA AQUINO, A. C. M., CARASEK, E., AMANTE, E. R. 2017. Study of Heat Treatment in Processing of Pumpkin Puree (Cucurbita moschata). Journal of Agricultural Science, 9(10), 234. ISSN 1916-9760. doi:10.5539/jas.v9n10p234

SARAH, B., MERIEM, M., NABIL, B., KAMEL, B., ALI, R. 2017. Antiinflammatory properties of the carotenoids and polyphenols of pumpkin (Cucurbita moschata Duchesne). South Asian Journal of Experimental Biology, 7(3), 100-106. ISSN: 2230-9799.

SHAHIDAN, N., JASWIR, I., OTHMAN, R., HASHIM, H., ZUHANIS, Y. 2014. Carotenoid content in different locality of pumpkin (Cucurbita moschata) in Malaysia. International Journal of Pharmacy and Pharmaceutical Sciences, 6(3), 29-32. ISSN- 0975-1491.
TAMER, C. E., INCEDAYI, B., YÖNEL, S. P., YONAK, S., COPUR, O. U. 2010. Evaluation of several quality criteria of low calorie pumpkin dessert. Notulae Botanicae Horti Agrobotanici Cluj-Napoca, 38(1), 76-80. ISSN 1842-4309.

doi: http://dx.doi.org/10.15835/nbha3813557

TAMILSELVI, N., JANSIRANI, P. 2017. Evaluation of Pumpkin (Cucurbita moschata L.) genotypes for earliness, yield and quality. International journal of current microbiology and applied sciences, 6(3), 1554-1559. ISSN 2319-7706. doi:https://doi.org/10.20546/ijcmas.2017.603.178

ZACCARI, F., GALEAZZI, D., RAHI, V. 2015. Efecto del tiempo de almacenamiento en condiciones controladas d temperatura sobre atributos físicos y químicos de zapallos "tipo kabutia"(Cucurbita maximax Cucurbita moschata). Revista Iberoamericana de Tecnología Postcosecha, 16(1), 114-120. ISSN 1665-0204.

ZACCARI, F., CABRERA, M. C., SAADOUN, A. 2017. Variation in glucose, $\alpha$-and $\beta$-carotene and lutein content during storage time in winter squash" type Butternut"[online]. ISHS Acta Horticulturae 1151, 273-278 https://doi.org/10.17660/ActaHortic.2017.1151.42

ZDUNIĆ, G. M., MENKOVIĆ, N. R., JADRANIN, M. B., NOVAKOVIĆ, M. M., ŠAVIKIN, K. P., ŽIVKOVIĆ, J. Č. 2016. Phenolic compounds and carotenoids in pumpkin fruit and related traditional products. Hemijska industrija, 70(4), 429-433. ISSN 2217-7426. doi:10.2298/hemind150219049z ZHANG, M. K., ZHANG, M. P., MAZOUREK, M., TADMOR, Y., LI, L. 2014. Regulatory control of carotenoid accumulation in winter squash during storage. Planta, 240(5), 1063-1074. ISSN 1432-2048. doi:10.1007/s00425-014$2147-6$

ZHAO, J., LIU, W., CHEN, D., SONG, Y., ZHANG, Y. Y., NI, Y. Y., LI, Q. H. 2015. Physico-chemical and antioxidant properties of different pumpkin cultivars grown in China. Advance Journal of Food Science and Technology, 9(4), 308316. ISSN 2042-4876. doi: $10.19026 /$ ajfst.9.2014 